\title{
Megachurches in the Religious Marketplace
}

\author{
Marc von der Ruhr
}

\section{1 \\ Introduction}

Megachurches represent a relatively new way of 'doing church'. Given the nature of their general success, their approach is likely to offer some insight as to how to be a successful church in a time when many other churches are losing congregants. As Thumma and Travis' book title, Beyond Megachurch Myths: What We Can Learn From America's Largest Churches (2007) suggests, much of what many think they know about megachurches may, in fact, be incorrect. This chapter explores the strategic efforts megachurches have employed in a volatile religious marketplace to better understand their success.

The chapter begins by characterising the marketplace of religion in the UsA in recent history, documenting the fluid nature of church membership resulting from a consumer driven approach to choosing a church. We then relate these trends to a significant literature drawn primarily from economics and sociology. The literature offers insights as to how and why churches succeed or fail, and then reconciles the lessons learned with the megachurch experience (the interested reader is directed to Iannaccone (1998) and Witham (2010) for comprehensive summaries of the academic literature on an economic approach to religion). In doing so, we will see that megachurches have been strategic by approaching the religious marketplace emphasising flexibility in their approach to supplying a religious product and allowing for a customised spiritual experience to attendees. We end by examining a challenge that many of the newer megachurches will need to face: that of managing pastoral succession.

The religious marketplace of the United States is well known to be a rather competitive one. There is no state sponsored monopoly church. Instead, the freedom of religion allows United States 'consumers' of religion to choose from a wide variety of religions and denominations. Likewise, religious 'entrepreneurs' have the freedom to open new churches with the hope of attracting new members. Megachurches have thrived in this environment. 
Since megachurches are a product of a competitive religious landscape, it will be helpful to consider some trends of religious participation in the United States to better contextualise how megachurches are structured. The Pew Research Center has recently published two expansive surveys of the USA religious landscape (see Pew 2008 and Pew 2015a). Each study was published the year after the survey was conducted and, in combination, they reflect many interesting facts about how religion is practiced in the USA, as well as how its practice is changing. Among the trends identified in the survey results are the following. Between 2007 and 2014, the share of the population identifying as Christian fell from 78.4 percent to 70.6 percent. This is primarily a function of a decline in Catholics and mainline Protestants. On the other end of the spectrum, the results indicate that churches in the evangelical Protestant tradition have shown modest gains in membership. The single largest growth was among the religiously unaffiliated (often referred to as 'nones').

Concomitantly, there has been a great amount of religious switching that has taken place. If Protestantism is treated as a single group, 34 percent of USA adults have switched from the religion in which they were raised. If we allow for some finer distinctions between the three major Protestant traditions (evangelical, mainline, and historically black Protestantism), the statistic rises to 42 percent. These trends are also reflected in the work by Kosmin and Keysar (2006). One last detail in the Pew surveys that will be important when we turn to megachurches is that when the Pew study provided detail in percentages of people leaving and joining a group, nondenominational churches saw a combined decrease in people leaving, and a gain in people joining the group. Thus, nondenominational churches, for whatever reason, seem to be doing well in our current religious marketplace. As we will see later in this chapter, megachurches are increasingly joining the ranks of nondenominational churches.

Last, though there are mixed results regarding winners and losers in the religious marketplace, with a general downward trend in religious belonging, measures of spirituality have simultaneously risen over these seven years. Survey questions about a deep sense of spiritual peace and well-being as well as a deep sense of wonder about the universe demonstrate increases across generations ranging from the silent generation to younger millennials.

\section{Megachurches' Recent Experience}

When it comes to data on megachurches, the Hartford Institute for Religion Research offer regular survey results describing their recent experience. The key authors summarising the data on megachurches are Scott Thumma, 
Warren Bird, and Dave Travis. Thumma et al. (2005), Thumma and Travis (2007), and Thumma and Bird $(2008,2011,2015)$ document trends in megachurch growth in the USA. Highlights they find in these surveys begin to paint the picture of how megachurches are structured to negotiate the tumultuous environment in which churches today find themselves. In addition, the trends identified shed light on why they have grown so successfully.

Between 2000 and 2005, the number of megachurches doubled, growing to 1,210. Their average 5 -year growth rate of megachurches founded between 1991 and 2005 was 424 percent, and their median attendance was 3,440. At the time of their 2008 survey, a result of note was that their attendance was rising without increases in their capacity, suggesting that megachurches were creative in offering more services and using multiple venues, sometimes on multiple campuses, to satisfy the demand for their services.

Another potentially enlightening fact found in the 2008 survey was that megachurches seemed to be moving away from finding pastors educated at formal pastoral schools and instead are generating their leadership from informal, internal internship programmes and clergy training. Megachurches are increasingly becoming their own replacements for denominations, thereby freeing themselves from external denominational authority. We saw evidence of this above in the increased presence of nondenominational churches. There is a movement away from specific Protestant distinctions to favouring the label of 'generic evangelism'.

In their summary of the analysis of their 2009 survey, Thumma and Bird mention that the continued growth of megachurches is fueled, in part, by new members accepting invitations by existing members to attend. Initial attractors included the church's reputation, worship style, and pastor's reputation. All of these factors also had a positive impact on long term attendance (along with the community, music/arts, and small groups). Thumma and Bird stress, and this arises with increasing frequency, that attendees are able to create a unique and customised experience through many channels that the megachurches provide. We return and discuss this in much more detail later in this chapter. There is a clear emphasis on the megachurch recognising that potential church members are consumers looking for an experience which satisfies their needs, and working to satisfy this inherent need. Since there will be diverse needs, it seems that pastors of these churches have been strategic in structuring the church to allow potential members the flexibility they require to create the experience that they want from a church.

Thumma and Bird comment on a number of common themes in their 2011 and 2015 surveys. They document continued growth, additional use of multisite facilities, multiple services offered both in terms of time and style, and 
increased denominational identity stated simply as 'evangelical'. An important thread to these findings that may likely be key to the megachurch phenomenon is adaptability, or flexibility. As examples of such flexibility, consider the following megachurch practices. Megachurches work to discover the perceived needs of potential members and accommodate these needs through a variety of services that can be fine-tuned to subsets of members' life stages and associated needs in the style and content of the service. Many megachurches employ a number of sites to make getting to church easier. They can broadcast their message though custom tailored social media. Megachurches offer small groups that cater to a variety of interests (both religious and secular). With the flexibility these practices offer, the megachurch is poised to be successful and grow.

We turn next to a brief review of the (mostly) economic literature applied to explaining religious outcomes and then more clearly explain how the deliberately chosen structure megachurches have adopted may have aided them in achieving their success.

\section{An Economic Approach to Religion}

Given that practicing religion is a behaviour and that it involves making choices, it is open to analysis through the lens of economics. We consequently first consider a marketplace for religion in order to more deeply explain the megachurch phenomenon. An excellent application of economic analysis to a religious marketplace is provided by Ekelund et al. (2006). They argue that since religion is a set of organised beliefs and that a church is an organised group of worshippers, it is wise to use economics to explain the behaviour of organised religion. They then proceed to carefully apply economic logic to trace the Protestant Reformation in reaction to the Catholic Church acting as a monopolist and in turn, the Catholic Church's counter-reformation.

The rise and fall of churches as evidenced by the fluid market described earlier begs the question of what makes a church succeed, or what makes a church strong. Iannaccone (1994) considers what makes a church strong, and comes to the somewhat counterintuitive conclusion that strict churches will be strong. Many at first think that this ought not be the case. If a church is strict, it is essentially charging a high price for membership and since demand curves tend to slope downward, we would expect to see less interest in the church. Iannaccone, however, astutely points out that the practice of a religion is better seen as a jointly produced experience, much like a book club, rather 
than an individual pursuit. As a result, the issue of free riding enters the analysis. When we consider the fact that in any club related activity, one person's satisfaction (or utility) is a function not only of his or her effort or contribution, but also of other people's contributions. Thus, we see that if members of the group free ride, they reduce the satisfaction of other member's in the group. For a church, this means making it too 'easy' to be a member may welcome such free riding behaviour. However, if the church is clear that it is strict, meaning that it requires significant sacrifice and/or stigma, it will attract only those which are fully dedicated to the church, resulting in a strong church. Interestingly, one strategy for these strict churches to further encourage members to be dedicated to the church is to make competing (often secular) activities unavailable. This then makes the church's substitute to the secular activity experience an increase in demand.

The framework of considering ourselves in two contexts, one as consumers of religious activity, and another as consumers of secular activity provides a useful framework for distinguishing a church from a sect, and borrows from the idea of changing the relative price of religious and secular activities. Iannaccone (1988) tackles the analytical issue of distinguishing between a church and a sect in a clever manner. There has been an on-going debate about how to properly define and distinguish these two forms of religious establishments. In the past, researchers have used differences in size, exclusivity or inclusiveness, how demanding expectations are, how much secular society is rejected, and income and religiosity of members to distinguish a church from a sect.

Iannaccone derives a model of church and sect that leads to comparative statics which are consistent with stylised facts listed above to distinguish these two types of religious organisations. His model focuses on normative conduct that impacts our opportunities in either secular or religious consumption. His model begins with an individual that maximises her utility by consuming a secular $(\mathrm{Z})$ and a religious $(\mathrm{R})$ good. Each good is a function of time (T), purchased goods $(\mathrm{X})$, experience and human capital $(\mathrm{S})$, and conduct $(\mathrm{C})$. Conduct is the key to the model. One's conduct is singular, that is to say, the model does not allow for people to have different modes of conduct in the different marketplaces. Thus a person's conduct affects both the consumption of the secular $(\mathrm{Z})$ and the religious $(\mathrm{R})$ goods. A kind of conduct that increases $R$ will reduce $Z$ and vice versa. A certain kind of conduct is accepted as a behavioural norm by a religion and maximises $R$. Another kind will maximise $\mathrm{Z}$.

A key result deals with shifting norms across $\mathrm{Z}$ and $\mathrm{R}$. If the norms diverge too much, it will force the individual to take an extreme position to either the 
secular or the religious. Further, it will lead to reduced tolerance. Extreme positions become preferred to moderate ones. Last, Iannaccone discusses the alternatives a sect must provide since they distance themselves from secular society. They must offer substitutes for Z, the secular activities.

Iannaccone $(1992,1994)$ empirically test these predictions. He finds that sect-like characteristics increase attendance, contributions, and prayers after controlling for a variety of demographic characteristics including age, gender, education, income, marital status, and region. However, these results must be balanced by Iannaccone's (1988) comment that strictness can be taken too far, resulting in restricting how much a sect may grow.

To summarise, due to the collective nature of producing a religious good, churches will want to reduce free riding so that adherents enjoy the greatest satisfaction from the experience since everyone attending is contributing. One attractive strategy to engender such behaviour is to require significant sacrifice of a church's membership in order to discourage potential free riders from attending a service.

It may be interesting to note at this point that many people perceive megachurches to be 'religion lite' given all of the flexibility they offer potential members. Clearly, they may be seen as such. Whether this is clearly true is a question to which we return later.

These insights are quite helpful in understanding some factors that help predict success in a static environment. However, we live in a time of speedy social changes, and churches exist in this environment. Thus, we ought to spend some time considering how some churches have responded to social norms changing.

Iannaccone and Miles (1990) extend the themes of Iannaccone's earlier work in a more dynamic context by considering shifting social norms. This is interesting in that it impacts how a person's conduct contributes to the production of the secular and religious products when a stable conduct interacts with changing norms. We may ask, as secular norms become more liberal (and more distant from religious norms) how people and the church will react? Iannaccone and Miles study the response of the Mormon Church to the changing roles of women recent history. In particular, they assess the impact of the Church's response to these changing roles on member commitment rates and conversion rates between $195^{\circ}$ and 1986 .

A church faces two major tensions as social norms change in a manner inconsistent with a church's teachings. First, a church supposedly teaches to a transcendent truth that ought not to change. If a church accommodates social change in its teachings, does it undermine its own authority? Second, it faces a potentially no win situation. If it accommodates a social change, it is likely to 
attract younger potential members which embrace such social change, but at the expense of alienating more established members that resist such change. On the other hand, if the church is intransient, it will likely fail to attract new members while satisfying existing members that resist social change.

Iannaccone and Miles gather data on how the Mormon Church had responded to changes in women's roles and how Mormon members responded to the Church's response. They find that the Church did respond to women's changing roles, but with a lag of approximately five years. The short run resistance to change led to a long run accommodation of social change. The inevitable dilemma of alienating one group to attract another played out for the Mormon Church. More established members participated less when the Church accommodated social change, but this outcome was outweighed by the increased participation by younger members. The Church tried to appease both groups by reaffirming traditional ideals while accommodating new roles and behaviours for women. As Iannacconne and Miles quote Tawney (1926) (Iannaconne and Miles 1990: 1245), the Mormon Church aspired to ".... flexibility in practice while maintaining purity of doctrine".

Iannaccone and Makowsky (2007) explore the nature of persistent religious regionalism. They note that, despite a very fluid labour market that often involves relocation in order to take a new job, the United States has historically demonstrated significant stability in its religious landscape: the south remains relatively religious while the west remains largely irreligious. The authors employ simulation techniques to model multiple interacting factors related to religious behaviour (social ties, denominational affiliation, past religious experience, and personal demographics) and integrate them into a religious landscape over space and time to investigate how various factors affect religious outcomes as people migrate. Their simulations allow for an emergent culture that combines characteristics of social conformity and preference for one's original religion.

Their simulation triggers a random move of an agent, and after the move the agent reevaluates her religious attributes. These are subject to her original attributes (determined by birth), her current attributes (that existed just before the move), and her new social environment (impacted by her new neighbours). They show that the desire for social conformity can lead agents to engage in religious switching so that they conform to the religious nature of the neighbourhood to which they moved, providing an explanation for the persistent religious regionalism.

Miller (2002) studies the importance of competition in the marketplace of religion. More specifically, the recent rise of market competition of churches gives reason to consider organisational and competitive aspects that fall under 
the umbrella of strategic management. Miller works to specify the role of management, inter-organisational rivalry, and the conditions of sustaining competitive advantages. Some of the key questions he outlines and comments on that are relevant to our work include how new religious organisations can remain viable, how they can gain and sustain advantages over other religious and secular offerings, and how to respond to rivals. Miller highlights the roles of social legitimacy, inimitability, and market segmentation as factors that promote success.

Miller (2002: 439) invokes Peter Berger's 1963 analysis which notes that historically, religious tradition could be authoritatively imposed. In contrast, more recent evidence suggests that it must now be marketed. It must be 'sold' given that customers are not forced to 'buy' the religious product. Thus, churches compete not only with other churches, but also with secular activities. As we will see, megachurches have embraced this fact and meaningfully addressed it with their strategies.

Among the factors that Miller identifies as contributing to a sustainable competitive advantage are for a church to project a credible commitment and social perception of legitimacy. These interact in an interesting way when it comes to a church segmenting the market, especially in light of our earlier discussion of strictness and a successful church. While sects may begin as very strict organisations, the sect-to-church literature notes that the strictness will be reduced for the group to grow and become a church, as we also saw in terms of the Mormon Church changing to accommodate modern roles for women.

A sense of social legitimacy may be impacted by a number of factors. Those relevant to megachurches will include the sheer size of the church, and the fact that many new members become members after being invited by friends who attend the megachurch. Further, megachurches' ability to adapt to the environment (react to market forces with flexibility) in a manner that reflects cultural continuity also contributes to their ability to attain and sustain credibility.

Megachurches have been strategic by advertising themselves as a 'second chance' church. In terms of the language of an economist, this strategy suggests that people unhappy with a previous church ought to feel as though they can transfer their religious capital to the megachurch with minimal depreciation of that capital. Previously, the theory would indicate that if a person engaged in religious switching, their religious capital (for example, their familiarity with religious teachings, customs, etc.) would be highly compromised. Megachurch leaders were quite forward looking to suggest this does not need to be the case if you switched to their church. 
In light of these theoretical factors that affect a church's ability to thrive, we turn next to some further discussion of strategies megachurches may employ to understand their success.

\section{5}

\section{Megachurch Strategies for Success}

The evidence provided thus far would suggest that churches face significant challenges in attracting and retaining members. The Pew studies $(2008,2015 \mathrm{a}$, $2015 \mathrm{~b}$ ) clearly show that there are significant social trends away from organised religion to a more personalised spirituality. Further, though a smaller share of strict churches are maintaining membership (along the lines suggested by the literature presented) more and more churches struggle to maintain membership in the marketplace.

Consequently, megachurches face some non-trivial headwinds in the modern marketplace for religion. Yet they seem to succeed. What strategies have they pursued in order to grow their congregations to attract at least 2,000 attendees to services each week? Among the tasks they must accomplish is to distinguish themselves from other churches, and to employ strategies to not just attract new members, but to maintain those people's enthusiasm to continue to attend services.

If we focus on seeker-oriented megachurches, we can most clearly understand the context for success. Rick Warren's (1995) account of growing Saddleback Church serves as an excellent case study. He grew Saddleback from a small group meeting in his living room to one of today's preeminent megachurches. The first key to Saddleback's success was to acknowledge the challenges any church faces: people are increasingly consumers of religion and feel very comfortable switching churches, denominations, or leaving religion altogether. Again, churches face competition not just from other churches, but also increasingly from secular activities. As a result, two key factors that a successful church must accomplish are to demonstrate that they are different from the churches others have left and to find an alternative strategy to strictness to overcome the free rider problem.

Rick Warren states explicitly in his book, The Purpose Driven Church, that he wanted to attract 'seekers' to his church. In other words, he was not interested in stealing members of other churches to populate his own. Rather, he wanted to bring people back to church that had previously left a church as unsatisfied attendees. This is no easy task, as the aspiring megachurch needs to convince potential attendees and future members that, though they were dissatisfied 
with a previous association with religion, they ought to give the new church a try.

Thumma (1996) argues that megachurches represent a unique spiritual organisation. They offer a new congregational life that accommodates changes in American society. As established above, megachurches often offer multiple services, employ different styles of services to target various interests in their congregation, and some even have multiple branches to serve their members. Megachurch pastors have gone so far as to poll people to better understand what people want from their experience. Consequently, megachurches excel at deliberately implementing strategies that attract new attendees and help them to become integrated in the church while minimising the potential of alienating members who have deepened their affiliation with the church (Thumma and Travis 2007).

Traditionally, most megachurches have been evangelical, but many have downplayed their denomination affiliation, at least while hosting activities that are intended for new(er) attendees. For example, Rick Warren notes (1995: 199) that Saddleback is doctrinally and financially affiliated with the Southern Baptist Convention (SBC). However, his concern that widespread misperceptions about the SBC may inhibit seekers from attending led him to a strategy to attract seekers first and only later educate them about the SBC. His logic being that after seekers have found a good fit between their needs and what the church offers, their concern about denominational affiliation will be less important. Moreover, as referenced earlier, the trend towards outright disassociation from any denominational affiliation has gained momentum. As we saw, this allows the megachurch increased flexibility in dealing with social change and accommodating members' potentially changing attitudes towards social movements and the church's response to them.

Megachurches have successfully challenged much of the conventional wisdom regarding strategies that will lead to a strong church discussed earlier. A notable example is that megachurches encourage growth by allowing the new attendees to participate as 'free riders' with very little or no expectation to tithe, volunteer time, or even learn about the church's doctrines. The church essentially bets on the idea that a subset of these free riders will feel a strong sense of connection with the megachurch and after that point, be willing to make the required sacrifices the church requires in order to be successful. By way of analogy, they follow a strategy along the lines of introductory pricing of a new product in which a firm takes a loss in order to encourage consumers to try the new product and once they discover that they like it, will pay the higher price in order to continue to consume it.

As briefly mentioned earlier, the approach taken by seeker-oriented megachurches to attract members often leads to a common myth that megachurches 
are 'religion-lite'. It is understandable that the combination of people with lower denominational loyalties and a consumerist mentality along with megachurches' efforts to provide a personalised religious message may suggest such a reputation. However, megachurches make significant efforts along these lines to become the path by which these individuals reconnect with God and in doing so they ask much of the people that become members. According to Thumma et al. (2005), megachurches are among the most successful churches today in attracting and retaining members, suggesting that they foster ongoing commitment and involvement of their members.

Work by Von der Ruhr and Daniels (2012a, 2012b) cite the aforementioned strategies and further offer a theoretical model that allows them to empirically test these theories. They begin by noting Warren's (1995) reflection that as he established Saddleback, he only expected of members of the church to contribute offerings, non-members were explicitly told that they are not expected to give. Both Warren (1995) and Thumma and Travis (2007) mention that seeker-oriented megachurches understand that seekers want anonymity and pastors wish to provide the required anonymity. Naturally, megachurches would then not make requirements of additional time and effort of seekers who are just becoming acquainted with the church early in their affiliation.

Von der Ruhr and Daniels (2012a) employ data from the FACT200o survey about megachurches to examine three questions that they argue offer evidence of a lower cost to attract new attendees to the megachurch. The survey questions ask about: (1) the number of services offered at different times during a weekend, (2) the variety of styles of services, and (3) the types of group activities that exist in which attendees may participate. The idea behind considering the answers to the first two of these questions is that, if the megachurch offers more services than the non-megachurch, the megachurch succeeds in making it easier on a person to fit attending a service into a busy schedule. Further, if the megachurch can offer different styles of services, the likelihood that one of those styles will match a given person's preferences rises, making the service more enjoyable and thereby lowering the perceived cost of attending. The data suggest that megachurches offer statistically significantly more services than non-megachurches on Saturdays, Sunday mornings and Sunday afternoons.

The FACT200o survey asks churches that hold more than one service per weekend, how varied or similar they are. The data again suggest that megachurches offer a larger range of styles than non-megachurches.

The last question listed addresses the types of groups that the megachurch offers. Von der Ruhr and Daniels (2012a, 2012b) study these groups and ask whether they may be a key factor in the success of megachurches. They speculate that the use of groups, in particular groups centred on secular activities, 
allow the megachurch to accomplish two important goals. First, megachurches can signal they are a different kind of church to people who had either left a church with which they had previously affiliated due to dissatisfaction, or to people who had not previously affiliated thinking a church could not offer activities interesting to them. Second, though Iannaccone (1994) stresses the strategy of requiring sacrifice or stigma to ensure full participation by members through discouraging free riding, he notes an alternative strategy is to subsidise religious participation (though he suggests this alternative is unlikely to be feasible). Megachurches astutely realised that by housing church groups based on secular interests, they would in fact be able to successfully subsidise religious participation. Members could enjoy, for example, a running group though the church and in joining it, simultaneously contribute to the church's life and incorporate a required run for the week. Further, we earlier saw that people are increasingly wanting a personalised religious or church experience. Being able to choose from a host of group activities offered by a megachurch, the ability to stitch together a personalised experience becomes much easier.

Megachurches offering a group related to a particular interest was statistically significantly greater than non-megachurches in the following themes: community service, parenting and marriage enrichment, choir, performing arts, book clubs, self-help groups, fitness activities, sports teams, and youth groups. Von der Ruhr and Daniels note that the percentage difference in the offering can become quite large. The difference is particularly large for secularly based activities such fitness activities (a 59 percent difference) and sports teams (a 57 percent difference). Clearly, megachurches are making it possible for people to engage in an activity that may not usually be church based, but bring it under the roof of the church.

In an effort to play devil's advocate to Von der Ruhr and Daniels, it may be argued that the ability to offer these groups is a function of a supply side effect. In other words, a larger church can offer more groups than a small church, and that these differences are not an outgrowth of a deliberate strategy. The authors investigate this potential criticism and find that the turning point in terms of offering these groups comes once the church experiences attendance rates between 200 and 500 weekly attendees. Thus, it seems as though the supply side argument is viable when comparing churches with 200 or fewer attendees to larger churches, but is not relevant to comparing megachurches to the churches with greater than 200 attendees.

Taken together, we see that seeker-oriented megachurches have found a strategy to both signal that they are a new way of doing church and also reduce the full price of participation for new attendees. Critics may argue that this strategy waters down the religious message of megachurches. Thumma and 
Travis (2007) argue that this is not the case and that members actually pay a high full price. Ease of entry remains for members, but the full price of participation may rise through other costs, requirements, and commitments that increase as affiliation rises.

The model outlined von der Ruhr and Daniels predicts that, subsequent to a seeker discovering a good fit, the church will raise its price. The FACT20oo survey asks three questions that we may look to in order to find evidence supporting the fact that the megachurches do expect more of members than of new attendees. The survey asks: (1) about the difficulty in getting people to volunteer, (2) about the expectations of members' personal practices outside of church and general strictness, and (3) about the existence of community outreach programmes. We follow the same approach as Bird (2007), and argue that all these activities would be most relevant to people who are further in their process of becoming members or are already members of the church.

The survey responses show that the church has less difficulty in recruiting volunteers, expects more of members in their personal practices away from home (personal prayer, scripture study, family devotions, fasting, and abstaining from pre-marital sex), and that the church is clearer and more strictly enforces its expectations of its members. Last, the megachurch has more outreach programmes/volunteer programmes than non-megachurches, suggesting that the megachurch can more effectively recruit its members to serve others than non-megachurches.

The evidence we have seen in the data suggests that the unconventional techniques used by megachurches, especially the use of small secular-interest based groups, are no accident and are a deliberate strategy to attract new attendees. The strategies are result of, in many cases, polling people to better understand what potential and actual members want and incorporating those wishes in church programming. Thumma and Travis (2007) note that some even employ church growth specialists to attract and retain new members. Putnam and Campbell (2010) go so far as to characterise American Evangelicals as innovative entrepreneurs in their efforts to grow their church, thereby reinforcing the argument here that megachurches have been structured in a thoughtful and strategic manner to create flexible routes to involvement and participation by members. Further, that this outcome is no accident. It is the result of careful planning and action.

Since the megachurch's strategy to grow is based on reaching out to religious refugees, it maintains a deliberate flexibility to respond to the perceived needs of potential members. Wuthnow (1994) points out that groups represent a good way to accommodate change as members' needs change and provide a church additional flexibility in adapting to social change. Thumma (1996) 
likewise notes that this approach can be seen not only in their institutional practices but also in their physical structures: both are designed to be flexible, anticipating adjustments that will allow for future growth. One important manifestation of their flexibility is the use of small groups based in many popular secular interests (for example, a fitness group or sports team) as a way to engage new attendees. The idea being that, as new attendees participate in these church-sponsored activities, they add to their religious capital.

One theme that arises as we take stock of the strategies of megachurches is that, at least to some extent, they have employed strategies which counter conventional wisdom with regard to how to be a successful church. As we saw in the previous section, they offer an initially low cost path to membership, and they subsidise participation via group activities. We must acknowledge, however, that for members who deepen their affiliation, megachurches resemble successful churches in requiring significant sacrifice of their members.

Thumma, et al. (2005), Thumma and Bird (2008, 2009, 2011, and 2015) track trends in USA megachurches. The use of small groups and the outreach discussed above seem to be key determinants of megachurch growth. However, some other trends seem vital to the exceptional growth we have witnessed in the megachurch phenomenon. The element that links them all together involve trends which allow the megachurch to be flexible and adapt to environmental changes. The first we address, and perhaps the lynch pin is that of decreased denominational affiliation. It was previously established that megachurches had initially down played denominational affiliation to attract potential members. As these annual reports document, megachurches are currently on a trend to drop denominational affiliation altogether and form their own quasi-denominational network of like-minded churches.

This is particularly powerful in light of another trend identified in the 2008 report stating that megachurches are shifting from formal pastoral schools toward informal on-the-job programmes and internships for clergy training. Being free of the oversight of a formal denominational hierarchy and even conducting in-house clergy training essentially changes the landscape of constraints that a church faces. In the same report, Thumma and Bird note a trend of megachurches turning away from distinctive theological segments within conservative Protestantism toward what they term a 'generic evangelicalism'. These trends combine to allow the megachurch enormous flexibility to respond to changes in their environment. 
If we consider all these noteworthy characteristics of megachurches we can easily understand the last point Thumma and Bird (2009: 1) share under their summary of the most prominent findings. They state, "Attenders can craft unique, customized spiritual experiences through the multitude of ministry choices and diverse avenues for involvement that the megachurches offer". In the same report, they note that megachurches have been able to allow participants to interact with the megachurch in their own terms allowing them to meet their own individualised needs. Thus, while the megachurch may well maintain a clear theological vision, it allows members to find many paths by which to embrace the church's message. Further, many have endowed themselves with the independence of denominational affiliation to make changes deemed necessary to respond to environmental factors.

Further, this structure of flexibility can be extended into the future and be considered as a consistent strategy rather than a departure from the church's identity. If the church has been embraced by past members precisely because it did respond to environmental changes, they are more likely to respect that it continues to do so. Additionally, the use of groups based on secular interests allows the church to scan the horizon for new interests that can become the focus of a group, thereby attracting new potential members. This strategy of flexibility offers the megachurch what is essentially a renewable resource for sustaining and growing the church.

Martin (2007) researched the structure and leadership of two different megachurches to more clearly understand how the small groups in big churches may contribute the megachurch's success. She notes that people are on a quest to find community and a yearning for the sacred. Given the size of megachurches, it is easy to think that people may feel anonymous among the hundreds or thousands of other attendees at a service. The use of small groups help to overcome the potential for feeling lost in the crowd. Once again, we see that historically, small churches were seen as being able to apply strict standards and larger churches less able to (thereby being perceived as lax). However, megachurches have been able to employ the small groups such that strictness can be accommodated by a large church.

One of the research questions Martin delves into is how the small groups are promoted and supported by the megachurch. Her time spent at the two different churches contributes to our understanding of different approaches applied, both with great success. At the first megachurch she visited, the groups were based on the interests of those who founded the group. Perhaps this is what we'd expect given the discussion of megachurches so far. It is no wonder, then, that many of these groups had ties to secular interests, but were offered through the church. Also of note is that these groups were open to outsiders. 
This fact is consistent with our previous discussion of megachurches using secular interest based groups to attract religious refugees. However, the second megachurch placed a significant emphasis on Bible Fellowship programmes. Thus, we see two distinctly different management styles: in the first, we see a 'bottom up' or rather organic approach to generating the small groups. In the second, we see a 'top-down' hierarchically organised approach to the use of small groups. In both cases, the small groups generate the ties between people that serve to bind them to the larger church.

To summarise, megachurches are successful religious enterprises at a time when many churches are struggling to maintain a stable membership in terms of size. USA consumers of religion are increasingly invoking their rights as consumers, seeking churches that can satisfy their preferences for not just a religious product, but an experience which satisfies the consumer on a number of levels. These include the type of service, the time of the service, the kind of facility in which the service is offered, and a host of ancillary activities that appeal to the attendee. In many of the cases we have discussed so far, this reaction to the fluid marketplace of religion has been the product of the pastor of the megachurch. It is in the pastor's entrepreneurial approach to selling religion in the modern marketplace that these innovative (perhaps even rebellious, given the traditional approach to religion and the traditional academic literature on what makes for a successful church) strategies have allowed megachurches so much success. Consequently, considering leadership and leadership succession at megachurches is an important focus if megachurches are to thrive after the original pastor retires. It is this issue to which we turn to next.

"Every pastor is an interim pastor" is the first sentence of the preface to "Next: Pastoral Succession That Works" by Vanderbloemen and Bird (2014: 9). This sentence is quite revealing in that it focuses attention on a topic inadequately addressed by so many churches (megachurches and non-megachurches alike). Succession should be a process rather than an event. Yet, for many understandable psychological reasons, too many megachurches do not have a thoughtful succession plan in place that involves all the stakeholders of the church in the process.

Founding pastors of megachurches definitely may be considered to be religious entrepreneurs. They surveyed the landscape of religion and created a new way to deliver a religious product to a segment of the population that was 
dissatisfied with the existing religious products other churches offered. However, as is well documented in the literature of entrepreneurial succession, the process is often difficult and frequently unsuccessful. For the megachurch, this can mean the transition from one pastor to another may make the difference between continued success, or the end of the megachurch. As Wheeler (2008) documents, following one early megachurch's pastor's departure, the church declined from a membership of 4,000 to just over 500 over the course of a decade.

Succession is an important topic to consider for the future of megachurches. Given that many have grown to be megachurches in recent history, it stands to reason that many will face succession issues in the future. Further, the transition in many cases will involve the religious entrepreneur responsible for the original growth of the church into a megachurch departing and handing control over to a new senior pastor. As Goldsmith (2009) points out, entrepreneurs tend to be driven, be a big deal in their community, be the go-to people, and have focused on their market for a long time. Filling these shoes can be a daunting task for any successor. Consequently, it will serve megachurches well to have a thoughtful succession plan in place. Though the literature points out that there is no 'one size fits all' plan, this section will borrow from Wheeler (2008) and Vanderloemen and Bird (2014) to point out some issues to consider relevant to successful succession plans.

One comment that Vanderloemen and Bird (2014) make is that they hope that churches will borrow what can be learned from secular businesses in their efforts to create succession plans that work. To that end, borrowing from the business literature, Wheeler (2008) notes that succession is both inevitable and introduces organisational instability and that the effectiveness of the successor is strongly impacted by the circumstances surrounding the previous leader's departure and the organisational knowledge of the successor. He goes on to note four sources of tension involved in organisational succession. These involve interpersonal issues in which the predecessor fails to hand over control to the successor, opposition to the successor within the organisation, generating the requisite 'buy-in' for a new style of management, and the perceived or real mismatch between the skills or knowledge of the successor and the skills knowledge needed for the job.

These issues suggest that finding the right pool of potential successors is critical for a megachurch. However, as Wheeler (2008) points out, the qualities needed to successfully lead a megachurch will likely offer a very small pool of potential successors; thereby highlighting the need to consider developing a process to identify and groom the best candidate(s). The stakeholders identified to be a part of the process include the departing pastor, the board of the 
megachurch, a transitional consultant that can offer objective opinions regarding the process, the personnel committee, and the incoming pastor.

Wheeler borrows from Collins (2005) in sharing an anecdote relevant to the challenge a new pastor will face coming into a church, especially in light of our modern consumer based religious switching in which a member may have more loyalty to a person (here, a departing pastor) than to the church. The anecdote references a CEO who was hired to serve as a dean presiding over a faculty, a subset of whom are tenured and consequently may feel free to voice disagreement with a new dean's policy proposals. Collins discusses two leadership styles; one is executive in nature and the other is characterised as legislative. The executive draws from concentrated power and decision making while the legislative involves a softer touch, borrowing more from the art of persuasion and leveraging social capital in order to create a positive environment for policy making.

Wheeler (2008) identifies key themes that megachurches shared in their succession experiences. They experienced ambiguity in the process and instability in the congregation. They noted the need for time for the successor to gain trust, change fatigue among those involved, and the need to transition other involved parties (for example, the elder board and staff) at the same time as the departing pastor left so that new loyalties to the successor pastor could be formed. These insights from management reveal that succession planning is hard work that must overcome many obstacles. Such planning, for obvious reasons, is also crucial for the on-going health of a megachurch.

In a marketplace of religion characterised by significant consumerism among potential members of churches, megachurches seem to be among churches that are gaining members when many other churches are losing members. The exact contributing factors can be debated, but the data and analysis seem to point to the emphasis megachurches have placed on flexibility to being a deliberate strategy they have employed in order to achieve the success we have seen. They maintain this flexibility in many aspects of their organisation, from the physical nature and décor of their place of worship, to the number and styles of services, to the nature of the small groups they employ to bring members under the umbrella of the larger church.

However, despite everything they have done well to thrive as an organisation, one challenge they face is how to maintain that level of success over time and across the leadership of different pastors. Developing and mentoring future 
generations of pastors that can clearly articulate and live the core of the church as it was founded, but also to extend the church into new directions to leverage its historical success is a challenging proposition. To the extent that megachurches can create a thoughtful plan that generates buy in from existing leaders and the congregation will help to sustain past success into the future.

\section{References}

Berger, P. 1963. "A Market Model For the Analysis of Ecumenity." Social Research 30, 77-93.

Bird, W. 2007. "Megachurches As Spectator Religion: Using Social Network Theory and Free-Rider Theory To Understand The Spiritual Vitality Of America's Largest-Attendance Churches." PhD. Fordham University, New York, NY, United States of America.

Collins, J. 2001. Good to Great. New York, NYH: Harper Collins.

Collins, J. 2005, Good to Great and the Social Sectors. Bouldar, Colombo. Jim Collins.

Ekelund, R., Hebert, R. and R. Tollison 2006. The Marketplace of Christianity. Cambridge, MA: MIT Press.

FACT2000. 2000. "Faith Communities Today". The Association of Religion Data Archives. At http://www.thearda.com/Archive/Files/Descriptions/FACTAG.asp. Accessed on o1/29/18.

Goldsmith, M. 2009. "Why Entrepreneurs Sabotage the Succession Process." Harvard Business Review. At https://hbr.org/2009/10/why-entrepreneurs-sabotage-the .Accessed 01/03/18.

Iannaccone, L. 1988. "A Formal Model of Church and Sect." The American Journal of Sociology. 94, S241-S268.

Iannaccone, L. 1992. "Sacrifice and Stigma: Reducing Free Riding in Cults, Communes, and Other Collectives." Journal of Political Economy. 100:2, 271-291.

Iannaccone, L. 1994. "Why Strict Churches are Strong." American Journal of Sociology. 99:5, 1180-1211.

Iannaccone, L. 1998. "Introduction to Economics of Religion." Journal of Economic Literature. $36: 3,1465^{-1495}$.

Iannaccone, L. and Makowsky, M. 2007. "Accidental Atheists? Agent-Based Explanations for the Persistence of Religious Regionalism." Journal for the Scientific Study of Religion. 46:1, 1-16.

Iannaccone, L. and Miles, C. 1990. “Dealing with Social Change: The Mormon Church's Response to Change in Women's Roles." Social Forces. 68:4, 1231-1250.

Kosmin, B. and Keysar, A. 2006. "Religion in a Free Market." Ithaca, NY, United States of America: Paramount Market Publishing. 
Martin, N. 2007. "Small Groups in Big Churches." PhD. The University of Arizona. Tucson, AZ, United States of America.

Miller, K.D. 2002. "Competitive Strategies of Religious Organisations." Strategic Management Journal. 23:5, 435-456.

Pew Research Center. 2008. "U.S. Religious Landscape Survey”. Pew Research Center. At http://www.pewforum.org/files/2013/05/report-religious-landscape-study-full .pdf. Accessed 03/08/17.

Pew Research Center. 2015a. "America's Changing Religious Landscape." Pew Research Center. At http://www.pewforum.org/2015/05/12/americas-changing-religious-land scape/. Accessed 04/11/15.

Pew Research Center. 2015b. "U.S. Becoming Less Religious". Pew Research Center. At http://www.pewforum.org/2015/11/o3/u-s-public-becoming-less-religious / .Accessed 04/11/15.

Putnam, R. and Campbell, D. 2010. American Grace: How Religion Divides and Unites Us. New York, NY: Simon and Schuster.

Tawney, R.H. 1926. Religion and the Rise of Capitalism: A Historic Study. 107th ed. London: J. Murray.

Thumma, S. 1996. "Exploring the Mega Church Phenomena: Their Characteristics and Cultural Context." Ph.D. Emory University, Atlanta, GA. United States of America.

Thumma, S. and Travis, D. 2007. Beyond Megachurch Myths: What We Can Learn from America's Largest Churches. San Francisco: Jossey-Bass.

Thumma, S. and Bird, W. 2008. "Changes In American Megachurches: Tracing Eight Years Of Growth And Innovation In The Nation's Largest-Attendance Congregations." Hartford Institute for Religion Research. At http://hirr.hartsem.edu/ megachurch/megachurches_research.html. Accessed 10/07/17.

Thumma, S. and Bird, W. 2009. "Not Who You Think They Are: The Real Story of People Who Attend America's Megachurches." Hartford Institute for Religion Research. At http://hirr.hartsem.edu/megachurch/megachurches_research.html. Accessed 10/07/17.

Thumma, S. and Bird, W. 2011. "A New Decade of Megachurches: 2011 Profile of Large Attendance Churches in the United States." Hartford Institute for Religion Research. At http://hirr.hartsem.edu/megachurch/megachurches_research.html. Accessed 10/07/17.

Thumma, S. and Bird, W. 2015. "Recent Shifts in America's Largest Protestant Churches: Megachurches 2015 Report." Hartford Institute for Religion Research. At http://hirr .hartsem.edu/megachurch/megachurches_research.html. Accessed 10/07/17.

Thumma, S., Travis, D. and W. Bird 2005. "Megachurches Today 2005: Summary of Research Findings." Hartford Institute for Religion Research. At http://hirr.hartsem .edu/megachurch/megachurches_research.html. Accessed 10/07/17. 
Vanderbloemen, W. and Bird, W. 2014. Next: Pastoral Succession That Works. Grand Rapids, MI: Baker Books.

Von der Ruhr, M. and Daniels, J. 2012a. "Explaining Megachurch Growth: Free Riding, Fit, and Faith.” International Journal of Social Economics. 39:5, 357-372.

Von der Ruhr, M. and Daniels, J. 2012b. "Subsidizing Religious Participation Through Groups: A Model of the 'Megachurch' Strategy for Growth." Review or Religious Research. 53:4, 471-491.

Warren, R. 1995. The Purpose Driven Church. Michigan: Zondervan.

Wheeler, M. 2008. "Leadership Succession Process In Megachurches." PhD. Temple University. Philadelphia, PA, United States of America.

Witham, L. 2010. Marketplace of the Gods: How Economics Explains Religion. Oxford: Oxford University Press.

Wuthnow, R. 1994. Sharing the Journey. New York, NY: The Free Press. 